\title{
Fruit Maturity and Storage Temperature Influence Response of Strawberries to Controlled Atmospheres
}

\author{
M.C.N. Nunes ${ }^{1}$ and A.M.M.B. Morais \\ Escola Superior de Biotecnologia, Universidade Católica Portuguesa, Rua Dr. António Bernardino de \\ Almeida, 4200 Porto, Portugal \\ J.K. Brecht and S.A. Sargent \\ Horticultural Sciences Department, University of Florida, Gainesville, FL, 32611-0690
}

\begin{abstract}
AdDitional INDEX wORDs. Fragaria $\times$ ananassa, decay, color, firmness, soluble solids, acids, anthocyanins
Abstract. 'Chandler' strawberries (Fragaria $\times$ ananassa Duch.) harvested three-quarter colored or fully red were stored in air or a controlled atmosphere (CA) of $5 \% \mathrm{O}_{2}+15 \% \mathrm{CO}_{2}$ at 4 or $10{ }^{\circ} \mathrm{C}$ to evaluate the influence of fruit maturity and storage temperature on the response to CA. Quality evaluations were made after 1 and 2 weeks in air or CA, and also after 1 and 2 weeks in air or CA plus 1 day in air at $20^{\circ} \mathrm{C}$. By 2 weeks, strawberries of both maturities stored in air at $10{ }^{\circ} \mathrm{C}$ were decayed, however, strawberries stored in $\mathrm{CA}$ at 4 or $10^{\circ} \mathrm{C}$ or air at $4{ }^{\circ} \mathrm{C}$ had no decay even after 2 weeks plus 1 day at $20^{\circ} \mathrm{C}$. Threequarter colored fruit stored in either air or $\mathrm{CA}$ remained firmer, lighter (higher $\mathrm{L}^{*}$ value) and purer red (higher hue and chroma values) than fully red fruit, with the most pronounced effect being on CA-stored fruit at $4{ }^{\circ} \mathrm{C}$. CA was more effective than air storage in maintaining initial anthocyanin and soluble solids contents (SSC) of three-quarter colored fruit and fruit stored at $10^{\circ} \mathrm{C}$. Strawberries harvested three-quarter colored maintained initial hue and chroma values for 2 weeks in $\mathrm{CA}$ at $4{ }^{\circ} \mathrm{C}$, becoming fully red only when transferred to air at $20^{\circ} \mathrm{C}$. Although three-quarter colored fruit darkened and softened in $10{ }^{\circ} \mathrm{C}$ storage, the $\mathrm{CA}$-stored fruit remained lighter colored and as firm as the at-harvest values of fully red fruit. After 1 or 2 weeks in CA at either 4 or $10^{\circ} \mathrm{C}$ plus 1 day at $20^{\circ} \mathrm{C}$, three-quarter colored fruit also had similar SSC levels but lower total anthocyanin contents than the initial levels in fully red fruit. CA maintained better strawberry quality than air storage even at an above optimum storage temperature of $10{ }^{\circ} \mathrm{C}$, but CA was more effective at the lower temperature of $4{ }^{\circ} \mathrm{C}$. Threequarter colored fruit responded better to $\mathrm{CA}$ than fully red fruit, maintaining better appearance, firmness, and color over 2 weeks storage, while achieving similar acidity and SSC with minimal decay development.
\end{abstract}

One of the most effective methods for preserving the quality of fresh fruit and vegetables is to store them in controlled atmosphere (CA) or modified atmosphere (MA). CA and MA storage combined with proper refrigeration can maintain the quality and extend the shelf life of strawberries by delaying softening and color changes, as well as by retarding depletion of soluble sugars, ascorbic acid (vitamin C), and other organic acids (Kader, 1992; Li and Kader, 1989; Nunes et al., 1995; Smith, 1992; Smith and Skog, 1992). In strawberries (Fragaria xananassa), one of the main benefits of using CA or MA is inhibition of decay by elevated $\mathrm{CO}_{2}$ (Smith, 1992; Woodward and Topping, 1972) and, to a lesser extent, the low levels of $\mathrm{O}_{2}$ used (Borecka and Millikan, 1981; Littlefield et al., 1966). Harker et al. (2000) recently suggested, based on measurements of electrical resistance of strawberry fruit apoplast and symplast, that elevated $\mathrm{CO}_{2}$ increases tissue firmness by reducing apoplast $\mathrm{pH}$ and thereby promoting precipitation of soluble pectins, which could enhance cell-to-cell bonding.

The optimum gas mixture for CA or MA is species dependent and, for strawberries, concentrations of $\mathrm{CO}_{2}>20 \%$ can cause development of off-flavors by increasing production of anaerobic metabolites such as ethyl acetate and ethanol (Larsen and Watkins, 1995a, 1995b; Ueda and Bai, 1993). Elevated $\mathrm{CO}_{2}$ levels (>20\%) can also cause undesirable color changes. Changes in color from red to dark red or purple have been attributed to differential synthesis

Received for publication 14 Sept. 2001. Accepted for publication 7 May 2002. This research was supported by the Florida Agricultural Experiment Station and a scholarship to M.C.N.N. from Junta Nacional de Investigação Científica e Tecnológica (JNICT), Portugal, and approved for publication as Journal Series No. R-05864. We thank Al Herndon of Ferris Farms, Floral City, Florida for cooperation in conducting this research.

${ }^{1}$ Corresponding author. Present address: Air Cargo Transportation Research Group, Department of Soils and Agrifood Engineering, Université Laval, St. Foy, Quebec, Canada G1K 7P4. and degradation of anthocyanins in the inner and outer tissues, and to modification in the anthocyanin type due to changes in fruit $\mathrm{pH}$ caused by high $\mathrm{CO}_{2}$ levels (Gil et al., 1997; Holcroft and Kader, 1999a, 1999b; Lidster et al., 1990).

Fruit injury due to exposure to high $\mathrm{CO}_{2}$ concentrations may be temperature dependent, since Woodward and Topping (1972) reported that the higher the temperature, the longer strawberries can be stored in $\approx 20 \% \mathrm{CO}_{2}$ without damage to the tissues. This could be due to reduced solubility of $\mathrm{CO}_{2}$ in the fruit at higher temperatures. There are several reports of off-flavor development in strawberries held at $\approx 20 \% \mathrm{CO}_{2}$ at 0 to $2^{\circ} \mathrm{C}$ (Larsen and Watkins, $1995 \mathrm{a} ; \mathrm{Li}$ and Kader, 1989; Ueda and Bai, 1993). Although ripe strawberries develop the strongest off-flavors, unripe fruit also develop off-flavors in $20 \% \mathrm{CO}_{2}$. High $\mathrm{CO}_{2}$ levels can also cause increases in $\mathrm{pH}$ and decreases in ascorbic acid content (Ke et al., 1991; McGill et al., 1966).

The $\mathrm{O}_{2}$ concentration in the storage atmosphere is also important, since at low levels of $\mathrm{O}_{2}$ the strawberry fruit can undergo a shift from aerobic to anaerobic respiration (Woodward and Topping, 1972). Ueda and Bai (1993) suggested that the critical $\mathrm{O}_{2}$ level at which strawberry fruit shift from aerobic to anaerobic respiration is lower than $1 \% \mathrm{O}_{2}$, and that the level is temperature dependent. For example, storage of strawberries at concentrations of $\leq 0.25 \% \mathrm{O}_{2}$ at 3 to $5{ }^{\circ} \mathrm{C}$ for more than 1 week may cause off-flavors as a consequence of anaerobic respiration (Couey et al., 1966; Ke and Kader, 1989). Perez and Sanz (2001) found that combinations of elevated $\mathrm{O}_{2}(80 \%$ or $90 \%)$ and $\mathrm{CO}_{2}(10 \%$ or $20 \%)$ at $8{ }^{\circ} \mathrm{C}$ exacerbated off-flavor development related to ethyl acetate and ethanol synthesis. Thus, the levels of $\mathrm{O}_{2}$ and $\mathrm{CO}_{2}$ that will extend shelf life without inducing fruit injury depend on time of exposure, storage temperature, and most likely other factors such as cultivar and fruit maturity (Harris and Harvey, 1973; Ke and Kader, 1992).

To prevent development of undesirable flavors as well as detrimental compositional changes, an appropriate CA composition 
should be selected for long storage periods of strawberries. Kader (1992) reported that atmospheres ranging from $5 \%$ to $10 \% \mathrm{O}_{2}$ plus $15 \%$ to $20 \% \mathrm{CO}_{2}$ are used for commercial shipping and storage of strawberries at 0 to $5^{\circ} \mathrm{C}$. The most common commercial MA system used in the United States entails use, in conjunction with refrigeration, of $\mathrm{CO}_{2}$-enriched atmospheres within sealed polyethylene pallet covers. Harvey et al. (1980) studied the effect of this system on strawberries shipped from California to east coast markets within the United States, and reported that fruit shipped in $10 \% \mathrm{CO}_{2}$ at $3{ }^{\circ} \mathrm{C}$ had only $5 \%$ decay, while strawberries shipped at $4{ }^{\circ} \mathrm{C}$ without elevated $\mathrm{CO}_{2}$ had $33 \%$ decay. Sommer et al. (1973) concluded that CA has little effect on strawberry decay at the optimum storage temperature of $0{ }^{\circ} \mathrm{C}$, however, strawberries are usually handled at temperatures from 2 to $10^{\circ} \mathrm{C}$ (Harvey et al., 1980; Sommer et al., 1973), which at least explains in part the commercial success of MA for strawberry shipping. We have reported previously (Nunes et al., $1995)$ that lower $\mathrm{O}_{2}$ levels (5\% vs. $10 \%$ ) are more effective in delaying softening and avoiding depletion of soluble sugars, ascorbic acid, and other organic acids of strawberries at these typical handling temperatures than elevated $\mathrm{CO}_{2}$ levels $(15 \%$ or $20 \%)$, which have relatively little effect. Since $20 \% \mathrm{CO}_{2}$ can cause undesirable changes in strawberry quality, an atmosphere of $5 \% \mathrm{O}_{2}$ $+15 \% \mathrm{CO}_{2}$ was selected for this study. Although the response of strawberries to CA and MA conditions has been relatively well studied compared to other fruit and vegetables, to our knowledge no previous studies have addressed the maturity or ripeness stage of strawberries for CA or MA. Therefore, the objective of this research was to evaluate the effect of initial fruit maturity on the response of strawberries to CA storage at 4 or $10^{\circ} \mathrm{C}$.

\section{Materials and Methods}

Plant Material. 'Chandler' strawberries were obtained from a commercial grower near Floral City, Florida. Strawberries were grown in double rows on raised beds covered with black plastic mulch, with drip irrigation and fertilization practices according to standard recommendations for strawberry production in Florida (Maynard et al., 1988). N-trichloromethylthio-4-cyclohexene-1,2dicarboximide (Captan; Drexel Chem. Co., Memphis, Tenn.) was applied weekly through the season at 3.36 to $6.72 \mathrm{~kg} \cdot \mathrm{ha}^{-1}$ up to 21.8 $\mathrm{kg}$ total along with up to four supplemental bloom applications (each at $2.24 \mathrm{~kg} \cdot \mathrm{ha}^{-1}$ ) of iprodione (Rovral; Aventis CropScience, Research Triangle Park, N.C.) for decay control. The experiment was conducted three times during Winter 1994-95 with identical treatments and storage times, but with minor modifications as to the measurements made.

Treatment AND STORAge CONDITIONS. Fruit with calyxes attached were commercially harvested in the morning and packed into fiberboard flats containing 12 plastic mesh pint (0.47-L) baskets. Packed fruit were removed from the field with minimal delay after harvest and transported from Floral City to the laboratory in Gainesville within $\approx 2$ h of harvest. Fruit were selected and divided into two maturity stages: three-quarter colored and fully red, but not overripe. Three-quarter colored fruit had red color on about $75 \%$ of the fruit surface, while fully red fruit were light red over the entire fruit surface. Fruit of each maturity stage were placed into 1.89-L glass jars containing 20 fruit each, with six jars for each atmosphere at each temperature, and were kept in the dark at 4 or $10^{\circ} \mathrm{C}$ and $90 \%$ to $95 \%$ relative humidity ( $\mathrm{RH})$, either in air or $5 \% \mathrm{O}_{2}+15 \% \mathrm{CO}_{2}$.

Air and CA treatments were established by supplying the jars with air or by mixing required volumes of air, $\mathrm{N}_{2}$, and $\mathrm{CO}_{2}$ at constant temperature and pressure using flow boards with needle valve flowmeters, respectively. Gas mixtures were split out to replicate jars with flowboards consisting of a barostat and glass capillary tubing for flow control. The total flow rate was set based on published respiration rates for strawberries (Hardenburg et al., 1986) so that the $\mathrm{CO}_{2}$ levels due to respiration would be maintained below $0.3 \%$. The flow rate at $4{ }^{\circ} \mathrm{C}$ was maintained at $0.5 \mathrm{~mL} \cdot \mathrm{s}^{-1}$, while at $10^{\circ} \mathrm{C}$ the flow was $2.3 \mathrm{~mL} \cdot \mathrm{s}^{-1}$ inside each jar. High humidity was established inside the jars by bubbling the air or gas mixture through water before entering the jars holding the fruit.

Incoming gas composition was monitored every $4 \mathrm{~d}$ by sampling at the inlet ports of the containers. The $\mathrm{O}_{2}$ and $\mathrm{CO}_{2}$ concentrations were determined with a gas chromatograph (Series 580; Gow-MAC Instr. Co., Bridgewater, N.J.) equipped with a thermal conductivity detector (TCD) connected to two columns, one $1.9 \mathrm{~m}$ long $\times$ $0.32 \mathrm{~cm}$ diameter packed with 80 to 100 mesh Porapack, and the other $3.35 \mathrm{~m}$ long $\times 0.48 \mathrm{~cm}$ diameter packed with 60 to 80 mesh Molecular Sieve $13 \times$. The flow rate for the carrier gas (helium) was $0.5 \mathrm{~mL} \cdot \mathrm{s}^{-1}$. The injector and detector temperatures were $90^{\circ} \mathrm{C}$ and the column oven was $40{ }^{\circ} \mathrm{C}$.

Six replicate samples of 10 fruit from each atmosphere composition and maturity stage at each temperature were removed from storage after 1 and 2 weeks of storage. Three of the samples were analyzed at the time of removal from storage and the remainder after an additional $1 \mathrm{~d}$ in air at $20{ }^{\circ} \mathrm{C}$ and $80 \%$ to $85 \% \mathrm{RH}$.

DECAY. The incidence of decay was recorded at the time of transfer from CA or air storage at 4 or $10^{\circ} \mathrm{C}$ to air at $20^{\circ} \mathrm{C}$, and again after $1 \mathrm{~d}$ in air at $20^{\circ} \mathrm{C}$.

Color. Surface color of 30 individual fruit per treatment was measured with a hand-held tristimulus reflectance colorimeter (model CR-200b; Minolta Corp., Ramsey, N.J.). Color was recorded using the CIE-L*a*b* uniform color space (CIE-Lab), and numerical values of $\mathrm{a}^{*}$ and $\mathrm{b}^{*}$ were converted into hue angle $\left(\tan ^{-1} \mathrm{~b}^{*} / \mathrm{a}^{*}\right)$ and chroma $\left[\left(\mathrm{a}^{* 2}+\mathrm{b}^{* 2}\right)^{1 / 2}\right]$ (Francis, 1980). The L* value is a useful indicator of darkening during storage, either from oxidative browning reactions or increasing pigment concentrations. The hue is an angle in a color wheel of $360^{\circ}$, with $0,90,180$, and 270 ${ }^{\circ}$ representing the hues red-purple, yellow, bluish-green, and blue, respectively, while chroma is the intensity or purity of the hue. Together, $\mathrm{L}^{*}$, hue, and chroma give an accurate description of the color of a sample.

Firmness. Firmness ( $3 \mathrm{~mm}$ deformation) of 30 individual fruit per treatment was measured at the widest part of the fruit, perpendicular to the long axis, with an Instron Universal Testing Instrument (Model 1132, Instron Corp., Canton, Ohio). A 50-kg load cell was used for firmness determinations. Crosshead speed was 16 $\mathrm{mm} \cdot \mathrm{s}^{-1}$. A $16 \mathrm{~mm}$ diameter convex tip Magness-Taylor type probe was used and data were plotted using a strip recorder at $5 \mathrm{~kg}$ full scale. This test measured individual fuit firmness based on the resistance of the fruit flesh to deformation by the probe. Results in kilogram force (kgf) were converted to Newtons $(\mathrm{N})$ using the following formula: $\mathrm{N}=\mathrm{kgf} \times 9.8$ (Kader, 1982).

SoLUBLE SOLIDS. Three replicate samples of 10 fruit per treatment were homogenized in a laboratory blender at high speed for $2 \mathrm{~min}$. The homogenates were centrifuged at $800 g_{\mathrm{n}}$ for $30 \mathrm{~min}$, filtered through cheesecloth, and the soluble solids contents (SSC) of the resulting clear juice samples were determined with an Abbé refractometer (Cambridge Instruments, Inc., Buffalo, N.Y.).

pH. The $\mathrm{pH}$ of the juice samples was determined using a $\mathrm{pH}$ meter (model 140; Corning Medical and Scientific Instruments, Medfield, Mass.) that had been standardized previously to $\mathrm{pH} 4$ and $\mathrm{pH} 7$.

TITRATABLE ACIDITY. Aliquots $(6.00 \mathrm{~g})$ of juice were diluted with $50 \mathrm{~mL}$ distilled water and titratable acidity (TA) determined by 
titration with $0.1 \mathrm{NNaOH}$ to an end point of $\mathrm{pH} 8.1$ with an automatic titrimeter (Fisher Scientific Co., Pittsburgh, Pa.). The results were converted to percentage citric acid in the juice $[(\mathrm{mL} \mathrm{NaOH} \times 0.1 \mathrm{~N}$ $\times 0.064 \mathrm{meq} / 6.00 \mathrm{~g}$ of juice $) \times 100]$.

Total ANTHOCYANINS. Aliquots $(2.00 \mathrm{~g})$ of homogenized strawberry fruit tissue were mixed in $18 \mathrm{~mL}$ of $0.5 \%(\mathrm{v} / \mathrm{v}) \mathrm{HCl}$ in methanol and held for $1 \mathrm{~h}$ at $4{ }^{\circ} \mathrm{C}$ to extract the pigment. The flocculate was removed by filtering the extract through a single layer of facial tissue and absorbance of the resulting clear liquid containing the pigments was measured at $520 \mathrm{~nm}$ (maximum absorbance for anthocyanins). Pigment content was calculated using the following formula: $\mathrm{A}_{520} \times$ dilution factor $\times$ [molecular weight $(\mathrm{MW})$ of pelargonidin-3-glucoside/molar extinction coefficient] where MW of pelargonidin $=433.2$ and the molar extinction coefficient $=2.908$ $\times 10^{4}$. Results were expressed as $\mathrm{mg} / 100 \mathrm{~g}$ fresh weight $(\mathrm{FW})$ of pelargonidin-3-glucoside (PGN) (Spayd and Morris, 1981).

Statistical analysis. A completely randomized design was used. Analysis of variance (ANOVA) was performed using the Statistical Analysis System computer package (SAS Institute, Inc., 1982). ANOVA was used to determine the main effects and interactions of atmosphere, maturity, and storage time, and overall treatment means were compared by least significant difference (LSD) at $P=0.05$. Due to high decay incidence in two of the three replicate experiments, which made other quality measurements impossible after 2 weeks storage, results are presented for one experiment only.

\section{Results and Discussion}

DECAY. Incidence of decay during storage was quite variable among the three replicate experiments that were conducted. Decay incidence after 2 weeks storage was $<20 \%$ for both three-quarter and fully red fruit in either air or $\mathrm{CA}$ at $4{ }^{\circ} \mathrm{C}$ in all tests. However, decay incidence was $100 \%$ for red fruit and ranged from $70 \%$ to $100 \%$ for three-quarter colored fruit after 2 weeks in air at $10{ }^{\circ} \mathrm{C}$; decay incidence in CA-stored fruit at $10{ }^{\circ} \mathrm{C}$ ranged from $60 \%$ to $100 \%$ for red fruit and from $0 \%$ to $100 \%$ for three-quarter colored fruit after 2 weeks. In the experiment for which results are being presented, there was no decay in fruit of either ripeness stage after $4^{\circ} \mathrm{C}$ storage, either at the time of transfer or after an additional day in air at $20^{\circ} \mathrm{C}$. However, $100 \%$ of the fruit stored in air at $10^{\circ} \mathrm{C}$ for 2 weeks were decayed at the time of transfer to $20^{\circ} \mathrm{C}$ and had to be discarded while the fruit stored in CA had no decay even after 2 weeks at $10^{\circ} \mathrm{C}$ plus $1 \mathrm{~d}$ in air at $20{ }^{\circ} \mathrm{C}$.

FIRMNESS. Ripe strawberry fruit are characterized by large cells and thin cell walls that contribute to the fragility of their structure. In unripe fruit, the cells are smaller and the cell walls thicker, which results in firmer texture. Cell expansion continues to the red-ripe stage (Perkins-Veazie, 1995). Liquification of the cell contents has also been noticed with ripening of the fruit (Szczesniak and Smith, 1969). Also, the pectolytic enzymes in strawberries contribute to the gradual pectin degradation and disarrangement of the cell wall observed with ripening (Huber, 1984). In the present study, strawberries harvested three-quarter colored were firmer than fully red fruit at the time of harvest (Table 1). This greater firmness was maintained during storage in both air and CA at $4{ }^{\circ} \mathrm{C}$. However, while fruit firmness decreased during storage, fruit of both ripeness stages stored in CA were firmer than those stored in air over the 2-week storage period. In a previous study, similar results were obtained with 'Chandler' strawberries stored in the same atmosphere and temperature (Nunes et al., 1995).

Table 1. Firmness and color of 'Chandler' strawberries harvested at different maturity stages and stored in air or CA at 4 or $10{ }^{\circ} \mathrm{C}$ for 1 or 2 weeks followed by 1 day in air at $20^{\circ} \mathrm{C}$.

\begin{tabular}{|c|c|c|c|c|c|c|c|c|c|}
\hline \multirow[b]{2}{*}{ Treatment } & \multirow[b]{2}{*}{ Maturity } & \multicolumn{4}{|c|}{$4^{\circ} \mathrm{C}$} & \multicolumn{4}{|c|}{$10^{\circ} \mathrm{C}$} \\
\hline & & $\begin{array}{c}\text { Firmness } \\
(\mathrm{N})\end{array}$ & $\mathrm{L}^{*}$ & Hue & Chroma & $\begin{array}{c}\text { Firmness } \\
(\mathrm{N})\end{array}$ & $\mathrm{L}^{*}$ & Hue & Chroma \\
\hline & Fully red & 7.3 & 34.4 & 25.4 & 40.8 & 7.3 & 34.4 & 25.4 & 40.8 \\
\hline \multicolumn{10}{|l|}{1 week } \\
\hline Air & $3 / 4$ colored & 8.4 & 38.3 & 32.2 & 46.1 & 7.5 & 36.9 & 28.7 & 44.5 \\
\hline CA & Fully red & 8.2 & 35.2 & 28.1 & 43.1 & 7.5 & 35.2 & 25.4 & 38.7 \\
\hline \multicolumn{10}{|c|}{1 week + 1 day @20 ${ }^{\circ} \mathrm{C}$} \\
\hline \multirow[t]{2}{*}{ Air } & $3 / 4$ colored & 6.4 & 38.2 & 31.5 & 44.3 & 6.9 & 36.6 & 28.9 & 43.3 \\
\hline & Fully red & 5.8 & 36.5 & 27.4 & 41.0 & 5.2 & 34.6 & 26.2 & 40.8 \\
\hline CA & $3 / 4$ colored & 8.0 & 40.0 & 33.9 & 44.6 & 7.5 & 38.7 & 30.4 & 41.7 \\
\hline \multirow[t]{2}{*}{ CA } & $3 / 4$ colored & 8.7 & 39.2 & 39.4 & 46.1 & 7.4 & 37.0 & 30.3 & 42.6 \\
\hline & Fully red & 7.7 & 37.1 & 29.5 & 43.2 & 5.8 & 33.8 & 24.7 & 39.0 \\
\hline \multicolumn{10}{|c|}{2 weeks + 1 day @20 ${ }^{\circ} \mathrm{C}$} \\
\hline \multirow[t]{2}{*}{ Air } & $3 / 4$ colored & 6.5 & 35.3 & 27.8 & 41.6 & $\mathrm{D}$ & $\mathrm{D}$ & $\mathrm{D}$ & $\mathrm{D}$ \\
\hline & Fully red & 5.4 & 34.9 & 26.6 & 39.1 & $\mathrm{D}$ & $\mathrm{D}$ & $\mathrm{D}$ & $\mathrm{D}$ \\
\hline \multirow[t]{2}{*}{ CA } & $3 / 4$ colored & 6.6 & 38.0 & 31.2 & 43.4 & 6.9 & 38.4 & 33.0 & 44.5 \\
\hline & Fully red & 5.7 & 35.8 & 27.1 & 41.5 & 6.1 & 34.8 & 27.4 & 39.9 \\
\hline $\mathrm{LSD}_{0.05}$ & & 0.4 & 0.9 & 1.3 & 1.0 & 0.6 & 1.3 & 1.9 & 1.6 \\
\hline
\end{tabular}

${ }^{\mathrm{z}}$ Mean separation within columns by LSD at $P=0.05, \mathrm{n}=30$.

${ }^{\mathrm{y}} \mathrm{D}=$ samples not analyzed due to decay. 
After 1 week at $4{ }^{\circ} \mathrm{C}$, there was no difference in the firmness of three-quarter colored fruit stored in air or CA. However, firmness of fully red fruit stored for 1 week at $4{ }^{\circ} \mathrm{C}$ was better maintained in $\mathrm{CA}$ than in air. The CA-stored fully red fruit were actually firmer after 1 week at $4{ }^{\circ} \mathrm{C}$ than at the time of harvest (Table 1 ). When transferred to air for $1 \mathrm{~d}$ at $20^{\circ} \mathrm{C}$ after 1 week in air or CA at $4{ }^{\circ} \mathrm{C}$, the firmness of the fruit decreased significantly (Table 1). Three-quarter colored fruit stored 1 week in $\mathrm{CA}$ at $4{ }^{\circ} \mathrm{C}$ maintained firmness better when transferred to air at $20^{\circ} \mathrm{C}$ than those stored in air at $4{ }^{\circ} \mathrm{C}$. This might be an example of the residual effect of CA storage reported by Li and Kader (1989). However, fully red fruit lost almost all the firmness advantages of 1 week of CA storage, softening upon transfer from $\mathrm{CA}$ at $4{ }^{\circ} \mathrm{C}$ to air at $20^{\circ} \mathrm{C}$ after 1 week of storage.

After 2 weeks at $4{ }^{\circ} \mathrm{C}$, three-quarter colored and fully red fruit stored in CA were both significantly firmer than fruit stored in air (Table 1). However, the strawberries softened more after transfer to air from CA storage than from air storage after 2 weeks at $4{ }^{\circ} \mathrm{C}$, such that there was no difference in firmness between air and CA-stored fruit after 2 weeks at $4{ }^{\circ} \mathrm{C}$ plus $1 \mathrm{~d}$ at $20^{\circ} \mathrm{C}$. Both air and CA-stored three-quarter colored fruit remained firmer than fully red fruit.

ANOVA indicated that for $4{ }^{\circ} \mathrm{C}$ storage, the atmosphere, maturity, and storage time all had significant effects on strawberry firmness (Table 2). There was also a significant interaction of atmosphere $\times$ storage time on fruit firmness, reflecting the fact that the effect of CA in maintaining fruit firmness was more apparent after 2 weeks at $4{ }^{\circ} \mathrm{C}$ than after 1 week, but the residual effect of $\mathrm{CA}$ after an additional day at $20^{\circ} \mathrm{C}$ was apparent only after 1 week of storage.

Like the strawberries stored at $4{ }^{\circ} \mathrm{C}$, three-quarter colored fruit were firmer than fully ripe fruit after 2 weeks in $\mathrm{CA}$ at $10^{\circ} \mathrm{C}$ plus 1 d in air at $20^{\circ} \mathrm{C}$ (Table 1). There was no firmness difference between air- or CA-stored fruit after 1 week at $10{ }^{\circ} \mathrm{C}$, but air-stored fruit softened more rapidly when transferred to air at $20{ }^{\circ} \mathrm{C}$ (Table 1 ). After 2 weeks in $\mathrm{CA}$ at $10^{\circ} \mathrm{C}$ plus $1 \mathrm{~d}$ in air at $20^{\circ} \mathrm{C}$, three-quarter colored fruit remained as firm as fully red fruit were at the time of harvest (Table 1).

Although no information was found about structural changes in strawberries during CA storage, it is well recognized that CA has a positive effect on strawberry texture by maintaining or even increasing fruit firmness (Larsen and Watkins, 1995a; Smith and Skog, 1992). El-Kazzaz et al. (1983) observed that strawberries stored in air plus $10 \%$ or $15 \% \mathrm{CO}_{2}$ for $21 \mathrm{~d}$ at $3.3^{\circ} \mathrm{C}$ were significantly firmer than those stored in air. Smith (1992) also reported that 'Redcoat' strawberries stored in $15 \% \mathrm{CO}_{2}$ for $18 \mathrm{~h}$ at $0^{\circ} \mathrm{C}$ were $48 \%$ firmer than initial samples but that there was no enhancement of firmness by $\mathrm{CO}_{2}$ at $21^{\circ} \mathrm{C}$. Similar results were reported by Larsen and Watkins (1995a) when 'Pajaro' fruit were stored in $20 \% \mathrm{CO}_{2}$ at $0^{\circ} \mathrm{C}$. Larsen and Watkins (1995b) found that firmness of CA-stored strawberries is enhanced by elevated $(\geq 4 \%) \mathrm{CO}_{2}$ levels and only slightly affected by reduced $(\geq 2 \%) \mathrm{O}_{2}$. They noted that unripe ( $25 \%$ to $50 \%$ red) 'Pajaro' strawberries had firmer texture than ripe ( $>50 \%$ red) fruit during $11 \mathrm{~d}$ storage at $0{ }^{\circ} \mathrm{C}$, but they did not discuss the effect of ripeness stage on the response to $\mathrm{CA}$. Our results indicate that, while the effect of CA vs. air storage in maintaining firmness of fully red strawberries was greater than for three-quarter colored fruit, the greater initial firmness of three-quarter colored fruit was still maintained over 2 weeks storage and, in addition, the firmness advantage of CA-stored strawberries over air-stored fruit was rapidly lost upon transfer from CA storage to air at $20^{\circ} \mathrm{C}$.

Color. After 1 or 2 weeks in air or CA at $4{ }^{\circ} \mathrm{C}$, strawberries harvested three-quarter colored were lighter (higher $\mathrm{L}^{*}$ value) than those harvested fully red (Table 1). Three-quarter colored fruit stored in CA were also lighter (higher $\mathrm{L}^{*}$ value) than those stored in air, but there was less difference between air-stored and CA-stored fully red fruit. After 2 weeks in CA at $4{ }^{\circ} \mathrm{C}$, three-quarter colored strawberries were still a clear red color, similar to their color at harvest, while CA-stored fully red fruit were a less pure, reddish purple color (lower hue and chroma values) (Table 1). However, both three-quarter colored and fully red CA-stored fruit had higher hue and chroma values than air-stored fruit. Holcroft and Kader (1999a) reported that the external chroma value of 'Selva' strawberries stored at $5^{\circ} \mathrm{C}$ increased with time, and the increase was greater in $\mathrm{CO}_{2}$-enriched atmospheres than in air. Sacks and Shaw (1993) also reported that strawberries stored in air darkened slowly during storage. In the present study, after an additional day in air at $20^{\circ} \mathrm{C}$, three-quarter colored strawberries stored in CA reddened (decreased in hue angle) considerably, but their color remained significantly different from air-stored fruit. In contrast, the color of fully red fruit was no longer significantly different from air-stored fruit after 2 weeks at $4{ }^{\circ} \mathrm{C}$ plus $1 \mathrm{~d}$ at $20^{\circ} \mathrm{C}$. Thus, atmosphere composition, fruit maturity, and storage time all interacted to affect the color of the strawberries stored at $4{ }^{\circ} \mathrm{C}$ as the inhibition of red color development by CA was maintained longer in the less ripe fruit (Table 2).

Table 2. Significance determined by ANOVA of the main effects (atmosphere, maturity, and storage time) and their interactions on firmness and color of 'Chandler' strawberries stored in air or CA at 4 or $10^{\circ} \mathrm{C}$.

\begin{tabular}{|c|c|c|c|c|c|c|c|c|}
\hline \multirow{3}{*}{$\begin{array}{l}\text { Source of } \\
\text { variation }\end{array}$} & \multicolumn{4}{|c|}{$4{ }^{\circ} \mathrm{C}$} & \multicolumn{4}{|c|}{$10^{\circ} \mathrm{C}$} \\
\hline & \multirow{2}{*}{$\begin{array}{c}\text { Firmness } \\
(\mathrm{N})\end{array}$} & \multicolumn{3}{|c|}{ Color } & \multirow{2}{*}{$\begin{array}{c}\text { Firmness } \\
\text { (N) }\end{array}$} & \multicolumn{3}{|c|}{ Color } \\
\hline & & $\overline{L *}$ & Hue & $\overline{\text { Chroma }}$ & & $\mathrm{L}^{*}$ & Hue & Chroma \\
\hline Atmosphere $(\mathrm{A})^{\mathrm{z}}$ & $* *$ & $* *$ & $* *$ & $* *$ & NS & NS & NS & $*$ \\
\hline Maturity $(\mathrm{M})^{\mathrm{y}}$ & $* *$ & $* *$ & ** & $* *$ & $* *$ & ** & $* *$ & $* *$ \\
\hline Storage time $(S)^{\mathrm{x}}$ & $* *$ & $* *$ & $* *$ & $* *$ & $* *$ & $* *$ & $* *$ & $* *$ \\
\hline \multicolumn{9}{|l|}{ Interactions } \\
\hline $\mathrm{A} \times \mathrm{S}$ & $*$ & $* *$ & $* * *$ & $* *$ & $*$ & NS & NS & NS \\
\hline $\mathrm{M} \times \mathrm{S}$ & NS & $* *$ & $* * *$ & $* *$ & NS & $* *$ & $* *$ & $*$ \\
\hline $\mathrm{A} \times \mathrm{M} \times \mathrm{S}$ & NS & $* *$ & $*$ & NS & NS & NS & NS & NS \\
\hline
\end{tabular}

${ }^{\mathrm{z}}$ Air and CA storage $\left(5 \% \mathrm{O}_{2}+15 \% \mathrm{CO}_{2}\right)$.

yThree-quarter colored and full ripe.

${ }^{\mathrm{x}} 1$ and 2 weeks at 4 or $10^{\circ} \mathrm{C}$, and 1 and 2 weeks at 4 or $10^{\circ} \mathrm{C}$ plus 1 day at $20^{\circ} \mathrm{C}$.

Ns,***,**** Nonsignificant or significant at $P=0.05,0.01$, or 0.001 , respectively. 
Color changes in fruit stored at $10^{\circ} \mathrm{C}$ were similar to those at 4 ${ }^{\circ} \mathrm{C}$ (Table 1). Thus, three-quarter colored fruit were lighter (higher $\mathrm{L}^{*}$ value) than fully red fruit after 2 weeks in CA at $10^{\circ} \mathrm{C}$ plus $1 \mathrm{~d}$ in air at $20^{\circ} \mathrm{C}$. Also, fully red fruit had lower hue and chroma values than three-quarter colored fruit, due to the more reddish-purple color of the fully red fruit as described previously for fruit stored at $4{ }^{\circ} \mathrm{C}$. At $10^{\circ} \mathrm{C}$, atmosphere had a significant effect only on chroma, while maturity and storage time affected all of the color values (Table 2). Overall, it seems that storage in $\mathrm{CA}$ at $10^{\circ} \mathrm{C}$ had minimal effect on strawberry color compared to air-stored samples. The differences in color noticed between fully red and three-quarter colored fruit at both 4 and $10{ }^{\circ} \mathrm{C}$ reflected mainly the initial color differences between the two maturities since the $\mathrm{L}^{*}$, hue, and chroma values all changed significantly during storage in three-quarter colored fruit while changing little in fully red fruit.

Smith and Skog (1992) observed that fruit storage in $15 \% \mathrm{CO}_{2}$ for $42 \mathrm{~h}$ at $0.5^{\circ} \mathrm{C}$ had no effect on color of several strawberry cultivars, but other researchers have reported that storage of 'Selva' and 'Pajaro' strawberries in high $\mathrm{CO}_{2}$ atmospheres inhibited red color development (Ke and Kader, 1989; Ke et al., 1991). However, these authors considered only the $\mathrm{a}^{*}$ value as a measure of strawberry color changes during storage. It may be that use of $\mathrm{L}^{*}$, hue, and chroma values together might offer more precision for evaluation of strawberry color changes than $a^{*}$ value alone. In a previous study, Nunes et al. (1995) reported similar results for fully red 'Chandler' strawberries stored in $5 \% \mathrm{O}_{2}+15 \% \mathrm{CO}_{2}$ at $4{ }^{\circ} \mathrm{C}$. CA-stored fruit were lighter (higher $\mathrm{L}^{*}$ value), more red (higher a* value), and had more intense color (higher chroma value) than fruit stored in air.
Chemical Characteristics. Three-quarter colored strawberries had lower $\mathrm{pH}$ than fully red fruit at the time of harvest (Table 3). Although small, the initial $\mathrm{pH}$ difference between three-quarter colored and fully red fruit was maintained during storage in air or CA at both 4 and $10{ }^{\circ} \mathrm{C}$. The $\mathrm{pH}$ of three-quarter colored strawberries decreased after 1 week in air at both temperatures but not in CA (Table 3). There was no change in $\mathrm{pH}$ of fully red fruit after 1 week in either air or CA. Although $\mathrm{pH}$ then increased after $1 \mathrm{~d}$ at $20^{\circ} \mathrm{C}$ in both air and CA-treated fruit, samples stored in CA at $4{ }^{\circ} \mathrm{C}$ for 1 week had a smaller increase than those stored in air at $4{ }^{\circ} \mathrm{C}$ (Table 3$)$. After 2 weeks at 4 or $10^{\circ} \mathrm{C}$, the $\mathrm{pH}$ of the fruit stored in CA was not statistically different from that of the initial samples. After an additional day at $20^{\circ} \mathrm{C}$, the $\mathrm{pH}$ was lower than the initial levels for air-stored fruit at $4{ }^{\circ} \mathrm{C}$ and $\mathrm{CA}$-stored fruit at both 4 and $10{ }^{\circ} \mathrm{C}$, but the decrease was greater for air-stored fruit (Table 3 ).

TA was not significantly different in three-quarter colored fruit compared to fully red fruit at the time of harvest (Table 3), however, fruit maturity and storage time at $4{ }^{\circ} \mathrm{C}$ had significant effects on the TA levels (Table 4). No significant changes in TA were noticed after 1 week in CA or air at 4 or $10{ }^{\circ} \mathrm{C}$ (Table 3). However, when transferred to air at $20^{\circ} \mathrm{C}$ for $1 \mathrm{~d}$, TA significantly decreased in fruit of both maturity stages from $4{ }^{\circ} \mathrm{C}$ storage but not $10^{\circ} \mathrm{C}$ storage, and that decrease was greater in fully red fruit. After 2 weeks, the TA of three-quarter colored and fully red fruit stored in air or CA at $4{ }^{\circ} \mathrm{C}$ or $\mathrm{CA}$ at $10^{\circ} \mathrm{C}$ was not different from the TA at the time of harvest (Table 3). In contrast to the significant loss of TA observed after transfer to $20{ }^{\circ} \mathrm{C}$ following 1 week of storage at $4{ }^{\circ} \mathrm{C}$, TA did not change during the additional day in air at $20^{\circ} \mathrm{C}$ following 2 weeks

Table 3. Chemical characteristics of 'Chandler' strawberries harvested at different maturity stages and stored in air or $\mathrm{CA}$ at 4 or $10{ }^{\circ} \mathrm{C}$ for 1 or 2 weeks followed by 1 day in air at $20^{\circ} \mathrm{C}$.

\begin{tabular}{|c|c|c|c|c|c|c|c|c|c|}
\hline Treatment & Maturity & \multicolumn{4}{|c|}{$4^{\circ} \mathrm{C}$} & \multicolumn{4}{|c|}{$10^{\circ} \mathrm{C}$} \\
\hline \multirow[t]{2}{*}{ Initial } & $3 / 4$ colored & $3.42^{\mathrm{z}}$ & 2.3 & 8.93 & 12.2 & 3.42 & 2.3 & 8.93 & 12.2 \\
\hline & Fully red & 3.48 & 2.2 & 9.57 & 20.4 & 3.48 & 2.2 & 9.57 & 20.4 \\
\hline Air & Fully red & 3.44 & 2.1 & 9.10 & 23.2 & 3.50 & 1.9 & 9.20 & 24.7 \\
\hline \multirow[t]{2}{*}{ CA } & $3 / 4$ colored & 3.40 & 2.4 & 9.10 & 14.3 & 3.41 & 2.3 & 9.13 & 15.4 \\
\hline & Fully red & 3.44 & 2.2 & 9.23 & 19.9 & 3.49 & 2.0 & 9.20 & 21.4 \\
\hline \multicolumn{10}{|c|}{1 week + 1 day @20 ${ }^{\circ} \mathrm{C}$} \\
\hline Air & $3 / 4$ colored & 3.55 & 2.0 & 8.57 & 20.1 & 3.54 & 2.1 & 7.57 & 20.9 \\
\hline \multirow[t]{2}{*}{ Air } & $3 / 4$ colored & 3.38 & 2.2 & 8.57 & 20.8 & $\mathrm{D}^{\mathrm{y}}$ & $\mathrm{D}$ & $\mathrm{D}$ & $\mathrm{D}$ \\
\hline & Fully red & 3.43 & 2.0 & 8.90 & 24.6 & $\mathrm{D}$ & $\mathrm{D}$ & $\mathrm{D}$ & $\mathrm{D}$ \\
\hline \multirow[t]{2}{*}{$\mathrm{CA}$} & $3 / 4$ colored & 3.40 & 2.3 & 8.93 & 14.9 & 3.45 & 2.2 & 8.40 & 15.9 \\
\hline & Fully red & 3.50 & 2.0 & 9.10 & 19.7 & 3.50 & 2.1 & 8.77 & 21.8 \\
\hline \multicolumn{10}{|c|}{2 weeks + 1 day @20 ${ }^{\circ} \mathrm{C}$} \\
\hline \multirow[t]{2}{*}{ Air } & $3 / 4$ colored & 3.34 & 2.4 & 8.70 & 21.8 & $\mathrm{D}$ & $\mathrm{D}$ & $\mathrm{D}$ & $\mathrm{D}$ \\
\hline & Fully red & 3.42 & 2.2 & 9.23 & 26.2 & $\mathrm{D}$ & $\mathrm{D}$ & $\mathrm{D}$ & $\mathrm{D}$ \\
\hline \multirow[t]{2}{*}{$\mathrm{CA}$} & $3 / 4$ colored & 3.39 & 2.3 & 9.53 & 17.5 & 3.38 & 2.4 & 9.33 & 19.2 \\
\hline & Fully red & 3.46 & 2.1 & 9.37 & 20.9 & 3.45 & 2.2 & 9.45 & 25.2 \\
\hline $\operatorname{LSD}_{0.05}$ & & 0.03 & 0.26 & 0.05 & 1.29 & 0.03 & 0.4 & 0.07 & 1.2 \\
\hline
\end{tabular}

${ }_{\mathrm{z}}$ Mean separation within columns by LSD at $P=0.05, \mathrm{n}=3$.

${ }^{\mathrm{y}} \mathrm{D}=$ Samples not analyzed due to decay. 
of storage at $4{ }^{\circ} \mathrm{C}$ (Table 3). Others have reported no differences in TA between strawberries stored in CA or air (Ke et al., 1991; Li and Kader, 1989). In a previous study, Nunes et al. (1995) reported either no difference or higherTA values inCA-stored 'Chandler' strawberries compared to air-stored fruit, depending on the harvest date. Gil et al. (1997) observed no significant variations in TA of 'Selva' strawberries stored in $10 \%$ or $20 \% \mathrm{CO}_{2}$. Changes in acidity during CA storage of other fruit have been ascribed to either reduction in the oxidative metabolism of organic acids or synthesis of organic acids following assimilation of $\mathrm{CO}_{2}$ by the fruit (Metlitskii et al., 1972).

SSC was significantly higher in fully red than in three-quarter colored strawberries at the time of harvest (Table 3). Atmosphere, fruit maturity, and storage time all had significant effects on SSC levels at both 4 and $10^{\circ} \mathrm{C}$ (Table 4). SSC decreased after 1 week at 4 or $10^{\circ} \mathrm{C}$ in both three-quarter and fully red strawberries stored in air, but only in fully red fruit stored in CA, and decreased further in those treatments after $1 \mathrm{~d}$ in air at $20^{\circ} \mathrm{C}$ (Table 3). In contrast, threequarter colored strawberries stored in CA had higher SSC after 1 week at 4 or $10{ }^{\circ} \mathrm{C}$ than their initial levels. A further increase occurred after $1 \mathrm{~d}$ at $20^{\circ} \mathrm{C}$ in three-quarter colored fruit stored in $\mathrm{CA}$ at $4{ }^{\circ} \mathrm{C}$, but the $\mathrm{SSC}$ declined slightly in three-quarter colored fruit from CA at $10{ }^{\circ} \mathrm{C}$. After 1 week in $\mathrm{CA}$ at $4{ }^{\circ} \mathrm{C}$ plus $1 \mathrm{~d}$ in air at 20 ${ }^{\circ} \mathrm{C}$, three-quarter colored fruit had SSC equal to fully red fruit at the time of harvest. After 2 weeks, only the SSC of three-quarter colored fruit stored in $\mathrm{CA}$ at $4{ }^{\circ} \mathrm{C}$ remained as high as the at-harvest SSC. The SSC then increased in all of the treatments during $1 \mathrm{~d}$ in air at $20^{\circ} \mathrm{C}$ following 2 weeks storage, especially after storage at $10^{\circ} \mathrm{C}$. Nunes et al. (1995) reported previously that SSC of 'Chandler' strawberries stored in CA were consistently higher than for fruit stored in air. The increases in SSC that occurred during $1 \mathrm{~d}$ at $20^{\circ} \mathrm{C}$ following 2 weeks storage at 4 or $10^{\circ} \mathrm{C}$ may have reflected degradation and solubilization of cell wall polyuronides and hemicelluloses associated with fruit softening (Huber, 1984; Woodward, 1972). Although in the present experiments fruit weight was not monitored, we believe that increases in SSC that we observed were not a result of water loss since RH inside the jars was maintained near saturation and, in contrast to fruit stored for 2 weeks, SSC levels declined further at 20 ${ }^{\circ} \mathrm{C}$ following 1 week of storage.

Fully red fruit had higher total anthocyanins than three-quarter colored fruit at the time of harvest (Table 3) and atmosphere composition, fruit maturity, and storage time all had significant effects on anthocyanin content at both 4 and $10^{\circ} \mathrm{C}$ (Table 4). The anthocyanin content of three-quarter colored strawberries stored in air increased about $40 \%$ at $4{ }^{\circ} \mathrm{C}$ and almost $70 \%$ at $10^{\circ} \mathrm{C}$ after 1 week (Table 3). The increases in anthocyanin content in three-quarter colored fruit stored for 1 week in CA at 4 or $10^{\circ} \mathrm{C}$ were much less, but still significant. The anthocyanin content of fully red fruit stored in air also increased during 1 week at either 4 or $10^{\circ} \mathrm{C}$, but CA-stored fully red fruit showed no change in anthocyanin levels after 1 week at either temperature (Table 3). Anthocyanin content increased further in three-quarter colored fruit from both air and CA and in CA-stored, fully red fruit between 1 week and 1 week plus $1 \mathrm{~d}$ at 20 ${ }^{\circ} \mathrm{C}$; anthocyanin content of fully red fruit from air storage at 4 or 10 ${ }^{\circ} \mathrm{C}$ for 1 week did not increase further when transferred to $20^{\circ} \mathrm{C}$.

Anthocyanins continued to increase in air-stored fruit during the second week of storage at $4^{\circ} \mathrm{C}$, but anthocyanin levels in CA-stored fruit at both 4 and $10^{\circ} \mathrm{C}$ remained the same between 1 and 2 weeks storage (Table 3). After 2 weeks storage plus $1 \mathrm{~d}$ at $20{ }^{\circ} \mathrm{C}$, anthocyanin content increased further in fully red fruit from $4^{\circ} \mathrm{C}$ air storage or $10^{\circ} \mathrm{C} \mathrm{CA}$ storage and in three-quarter colored fruit from CA storage at 4 or $10^{\circ} \mathrm{C}$. Anthocyanin levels were always lower in CA-stored fruit than in air-stored fruit, and the final anthocyanin levels were lower in fruit from $4{ }^{\circ} \mathrm{C} \mathrm{CA}$ storage than in fruit from 10 ${ }^{\circ} \mathrm{C} \mathrm{CA}$ storage. The final anthocyanin contents of CA-stored threequarter colored strawberries at both 4 and $10^{\circ} \mathrm{C}$ remained lower than the initial levels in fully red fruit. The final anthocyanin content in fully red fruit stored in CA at $4{ }^{\circ} \mathrm{C}$ was not different from the level at harvest, while that of $10{ }^{\circ} \mathrm{C} \mathrm{CA}$-stored fruit was higher. In contrast, Li and Kader (1989) observed that exposure of 'Selva' strawberries to $0.5 \% \mathrm{O}_{2}+20 \% \mathrm{CO}_{2}$ for $4 \mathrm{~d}$ at $2{ }^{\circ} \mathrm{C}$ retarded reddening of the fruit flesh but had no significant effect on the color of the skin, and Picón et al. (1993) reported that anthocyanin content increased during storage of 'Chandler' strawberries in $7 \% \mathrm{O}_{2}+14 \% \mathrm{CO}_{2}$ at 2 ${ }^{\circ} \mathrm{C}$ for $11 \mathrm{~d}$. Gil et al. (1997) noted that exposure of strawberries to $10 \%$ to $40 \% \mathrm{CO}_{2}$ at $5{ }^{\circ} \mathrm{C}$ for 5 or $10 \mathrm{~d}$ decreased their anthocyanin content, but that the effect was limited to the internal tissues. In agreement with our present study, Holcroft and Kader (1999a, $1999 b$ ) found that anthocyanin concentrations of 'Selva' strawberries stored at $5^{\circ} \mathrm{C}$ for $10 \mathrm{~d}$ increased both in air and in $20 \% \mathrm{CO}_{2}$, but the increase was lower in fruit stored in elevated $\mathrm{CO}_{2}$.

Table 4. Significance determined by ANOVA of the main effects (atmosphere, maturity, and storage time) and their interactions on chemical characteristics of 'Chandler' strawberries stored in air or CA at 4 or $10^{\circ} \mathrm{C}$.

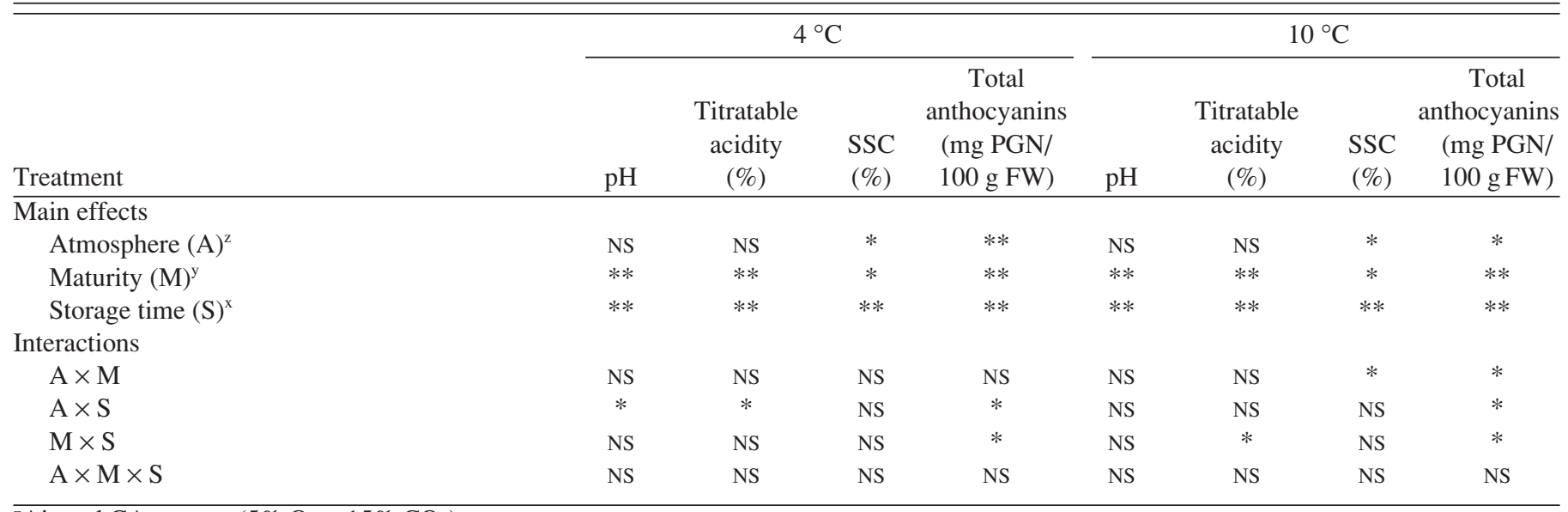

${ }^{\mathrm{z}}$ Air and CA storage $\left(5 \% \mathrm{O}_{2}+15 \% \mathrm{CO}_{2}\right)$.

yThree-quarter colored and fully ripe.

${ }^{\mathrm{x}} 1$ and 2 weeks at 4 or $10^{\circ} \mathrm{C}$, and 1 and 2 weeks at 4 or $10^{\circ} \mathrm{C}$ plus 1 day at $20^{\circ} \mathrm{C}$.

Ns,***,**** Nonsignificant or significant at $P=0.05,0.01$, or 0.001 , respectively. 


\section{Conclusions}

Strawberries at the three-quarter colored ripeness stage were firmer, had equal TA, lower $\mathrm{pH}$, lower SSC, and lower total anthocyanins than fully red fruit at harvest. Storage of strawberries in $\mathrm{CA}$ at either 4 or $10^{\circ} \mathrm{C}$ delayed fruit softening and maintained better color than air storage, and greatly reduced decay at $10{ }^{\circ} \mathrm{C}$, especially in fully red fruit. Thus, after 2 weeks storage in $5 \% \mathrm{O}_{2}+$ $15 \% \mathrm{CO}_{2}$ at either 4 or $10^{\circ} \mathrm{C}$ plus $1 \mathrm{~d}$ at $20^{\circ} \mathrm{C}$, three-quarter colored strawberries remained firmer and had higher $\mathrm{L}^{*}$, hue and chroma values, lower anthocyanin content, lower $\mathrm{pH}$, and similar TA and SSC contents compared with values for freshly harvested fully red fruit. Maintenance of firmness and color by CA was better at $4{ }^{\circ} \mathrm{C}$ than at $10^{\circ} \mathrm{C}$, but the differences between the storage temperatures was largely lost after transfer to air at $20^{\circ} \mathrm{C}$ for $1 \mathrm{~d}$ following 2 weeks storage. Overall, no significant differences were found in the $\mathrm{pH}$ and TA of fruit of the same maturity stored in air vs. CA for 2 weeks at $4^{\circ} \mathrm{C}$, however, SSC levels were higher and total anthocyanins lower in CA-stored strawberries. Decay of air-stored fruit at $10{ }^{\circ} \mathrm{C}$ precluded comparisons to CA-stored fruit after 2 weeks storage.

Results indicate that CA storage is more effective at $4{ }^{\circ} \mathrm{C}$ than 10 ${ }^{\circ} \mathrm{C}$ in maintaining strawberry quality. Strawberries harvested when three-quarter colored respond better to CA storage, maintaining greater firmness and better color than fully red fruit while reaching comparable SSC and acid levels and developing much less decay.

\section{Literature Cited}

Borecka, H. and D.F. Millikan. 1981. Influence of storage conditions upon the development of postharvest gray-mold rot of strawberries. Phytoprotection 62:11-16.

Couey, H.M., M.N. Follstad, and M. Uota. 1966. Low-oxygen atmospheres for control of postharvest decay of fresh strawberries. Phytopathology 56:1339-1441.

El-Kazzaz, M.K., N.F. Sommer, and R.J. Fortlage. 1983. Effect of different atmospheres on postharvest decay and quality of fresh strawberries. Phytopathology 73:282-285.

Francis, F.J. 1980. Color quality evaluation of horticultural crops. HortScience 15:58-59.

Gil, M.I., D.M. Holcroft, and A.A. Kader. 1997. Changes in strawberry anthocyanins and other polyphenols in response to carbon-dioxide treatments. J. Agr. Food Chem. 45:1662-1667.

Hardenburg, R.E., A.E. Watada, and C.Y.Wang. 1986. The commercial storage of fruits, vegetables, and florist and nursery stocks. USDA Hdbk. 66.

Harker, F.R., H.J. Elgar, C.B. Watkins, P.J. Jackson, and I.C. Hallett. 2000. Physical and mechanical changes in strawberry fruit after high carbon dioxide treatments. Postharvest Biol. Technol. 19:139-146.

Harris, C.M. and J.M. Harvey. 1973. Quality and decay of California strawberries stored in $\mathrm{CO}_{2}$-enriched atmospheres. Plant Dis. Rptr. 57:44-46.

Harvey, J.M, C.M. Harris, W.J. Tietjen, and T. Seriol. 1980. Quality maintenance in truck shipments of California strawberries. Adv. Agr. Technol. AAT-W-12. U.S. Dept. Agr., Sci. Educ. Admin., Wash., D.C.

Holcroft, D.M. and A.A. Kader. 1999a. Carbon dioxide-induced changes in color and anthocyanin synthesis of stored strawberry fruit. HortScience 34:1244-1248.

Holcroft, D.M. and A.A. Kader. 1999b. Controlled atmosphere-induced changes in $\mathrm{pH}$ and organic acid metabolism may affect color of stored strawberry fruit. Postharvest Biol. Technol. 17:19-32.

Huber, D.J. 1984. Strawberry fruit softening: The potential roles of polyuronides and hemicelluloses. J. Food Sci. 49:1310-1315.

Kader, A.A. 1982. Proper units for firmness and abscission force data. HortScience 17:707.

Kader, A.A. 1992. Modified atmospheres during transport and storage, $p$. 85-92. In: A. A. Kader (ed.). Postharvest technology of horticultural crops. Univ. Calif. Div. Agr. Natural Resources, Berkeley, Publ. 3311.

Ke, D., L. Goldstein, M. O’Mahony, and A.A. Kader. 1991. Effects of short-term exposure to low $\mathrm{O}_{2}$ and high $\mathrm{CO}_{2}$ atmospheres on quality attributes of strawberries. J. Food Sci. 56:50-54.

Ke, D. and A.A. Kader. 1989. Tolerance and responses of fresh fruits to low oxygen levels at or below 1\%, p. 209-216. In: J.K. Fellman (ed.). Proc. 5th Intl. Controlled Atmosphere Res. Conf., vol. 2, Wenatchee, Wash., 14-16 June, 1989.

Ke, D. and A.A. Kader. 1992. Potential of controlled atmospheres for postharvest insect disinfestation of fruits and vegetables. Postharvest News Info. 3(2):31N.

Larsen, M. and C.B. Watkins. 1995a. Firmness and aroma composition of strawberries following short-term high carbon dioxide treatments. HortScience 30:303-305.

Larsen, M. and C.B. Watkins. 1995b. Firmness and concentrations of acetaldehyde, ethyl acetate and ethanol in strawberries stored in controlled and modified atmospheres. Postharvest Biol. Technol. 5:39-50.

Li, C. and A.A. Kader. 1989. Residual effects of controlled atmosphere on postharvest physiology and quality of strawberries. J. Amer. Soc. Hort. Sci. 114:629-634.

Lidster, P.D., G.D. Blanpied, and R.K. Prange. 1990. Controlled-atmosphere disorders of commercial fruits and vegetables. Agr. Can. Publ. $1847 /$ E.

Littlefield, N.A., B.N. Wankier, D.R. Salunkhe, and J.N. McGill. 1966. Fungistatic effects of controlled atmosphere. Applied Microbiol. 14:579_ 580.

Maynard, D.N., G.J. Hochmuth, and M. Sherman. 1988. Strawberry production guide for Florida. Univ. of Fla. Inst. Food and Agr. Sci. Fla. Coop. Ext. Serv. Circ. 142C.

McGill, J.N., A.I. Nelson, and M.P. Steinberg. 1966. Effects of modified storage atmospheres on ascorbic acid and other quality characteristics of spinach. J. Food Sci. 31:510-517.

Metlitskii, L.V., E.G. Sal'kova, N.L. Volkind, V.I. Bondarev, and V.Y. Yanyuk. 1972. Controlled atmosphere storage of fruits. USDA-Natl. Sci. Foundation, Wash., D.C.

Nunes, M.C.N., A.M.M.B. Morais, J.K. Brecht, and S.A. Sargent. 1995. Quality of strawberries after storage in controlled atmospheres at above optimum storage temperatures. Proc. Fla. State Hort. Soc. 108:273-278.

Perez, A.G. and C. Sanz. 2001. Effect of high-oxygen and high-carbondioxide atmospheres on strawberry flavor and other quality traits. J. Agr. Food Chem. 49:2370-2375.

Perkins-Veazie, P. 1995. Growth and ripening of strawberry fruit. Hort. Rev. 17:267-297.

Picón, A., J.M. Martínez-Jávega, J. Cuquerella, M.A. Del Río, and P. Navarro. 1993. Effects of precooling, packaging film, modified atmosphere and ethylene absorber on the quality of refrigerated Chandler and Douglas strawberries. Food Chem. 48:189-193.

Sacks, E.J. and D.V. Shaw. 1993. Color change in fresh strawberry fruit of seven genotypes stored at $0{ }^{\circ} \mathrm{C}$. HortScience 28:209-210.

SAS Institute, Inc. 1982. SAS user's guide: Statistics. SAS Inst., Cary, N.C. Smith, R.B. 1992. Controlled atmosphere storage of 'Redcoat' strawberry fruit. J. Amer. Soc. Hort. Sci. 117:260-264.

Smith, R.B. andL.J.Skog. 1992. Postharvestcarbondioxide treatmentenhances firmness of several cultivars of strawberry. HortScience 27:420-421.

Sommer, N.F., R.J. Fortlage, F.G. Mitchell, and E.C. Maxie. 1973. Reduction of postharvest losses of strawberry fruits from gray mold. J. Amer. Soc. Hort. Sci. 98:285-288.

Spayd, S.E. and J.R. Morris. 1981. Effects of immature fruit and holding on strawberry puree and color stability. J. Amer. Soc. Hort. Sci. 106:211216.

Szczesniak, A.S. and B.J. Smith. 1969. Observations on strawberry texture: A three-pronged approach. J. Texture Studies 1:65-89.

Ueda, Y. and J-H. Bai. 1993. Effect of a short exposure of elevated $\mathrm{CO}_{2}$ on flesh firmness and ester production of strawberry. J. Jpn. Soc. Hort. Sci. 62:457-464.

Woodward, J.R. 1972. Physical and chemical changes in developing strawberry fruits. J. Sci. Food Agr. 23:465-473.

Woodward, J.R. and A.J. Topping. 1972. The influence of controlled atmospheres on the respiration rates and behavior of strawberry fruits. J. Hort. Sci. 47:547-553. 